\title{
Zmiany w stosunku służbowym funkcjonariuszy państwowej służby cywilnej w II Rzeczypospolitej
}

W początkowym okresie II Rzeczypospolitej sytuację prawną urzędników regulowały Tymczasowe przepisy stużbowe dla urzędników państwowych wydane przez Radę Regencyjną 11 czerwca $1918 \mathrm{r}$. Charakterystyczne dla tego aktu prawnego było nadanie stosunkowi łączącemu urzędnika z państwem charakteru publicznoprawnego. Nawiązanie stosunku służbowego następowało na podstawie mianowania ${ }^{1}$.

Tymczasowe przepisy obowiązywały do czasu uchwalenia ustawy z 17 lutego 1922 r. o państwowej służbie cywilnej, w której uregulowano w sposób kompleksowy status prawny urzędników. Weszła ona w życie 1 kwietnia 1922 r. a obowiązywała aż do 31 grudnia 1974 r., tzn. do jej uchylenia na podstawie art. IV $\S 1$ pkt 2 ustawy z dnia 26 czerwca 1974 r. - Przepisy wprowadzające Kodeks pracy $^{2}$. Normom u.p.s.c. podlegali wszyscy zatrudnieni w urzędach administracji

${ }^{1}$ Dziennik Praw Państwa Polskiego, nr 6, poz. 13; J.S. Langrod, Stużba państwowa (przepisy pragmatyczne i uposażeniowe), [w:] K.W. Kumaniecki, J.S. Langrod, Sz. Wachholz, Zarys ustroju, postepowania i prawa administracyjnego w Polsce, Kraków-Warszawa 1939, s. 742; J. Stelina, Prawo urzędnicze w II Rzeczypospolitej, „Gdańskie Studia Prawnicze”, t. XV, 2006, s. 334; W. Witkowski, Historia administracji w Polsce 1764-1989, Warszawa 2007, s. 370; E. Ura, Prawo urzędnicze, Warszawa 2011, s. 50; A. Dubowik. Ł. Pisarczyk, Prawo urzędnicze, Warszawa 2011, s. 52. W Tymczasowych przepisach... brak było przepisów określających zasady dokonywania zmian w stosunku służbowym łączącym urzędników i państwo.

2 Dz.U. nr 24, poz. 142; J.S. Langrod, op. cit., s. 742; J. Stelina, Prawo urzędnicze w II Rzeczypospolitej, s. 339; idem, Prawo urzędnicze, Warszawa 2017, s. 40; W. Jaśkiewicz, Sytuacja prawna pracowników państwowych, t. I: Formy prawne slużby państwowej $w$ niemieckim prawie urzędniczym. Stosunek stużbowy w prawie urzędniczym RP, Poznań 1961, s. 92-93; E. Ura, op. cit., s. 50, 52; Dz.U. nr 21, poz. 164; W. Witkowski, op. cit., s. 371; A. Dubowik. Ł. Pisarczyk, 
państwowej czyli rządowej. Nie odnosiły się one natomiast do sędziów, prokuratorów, aplikantów sądowych oraz pracowników zatrudnionych w przedsiębiorstwach państwowych (np. PKP czy poczcie), szkolnictwie państwowym czy woj$\mathrm{sku}^{3}$. Funkcjonariusze państwowej służby cywilnej dzielili się na dwie kategorie: urzędników i niższych funkcjonariuszy państwowych. Sytuacja prawna obydwu tych grup nie różniła się znacząco. Nawiązanie stosunku służbowego w obu przypadkach następowało na podstawie mianowania. Rozróżniano urzędników mianowanych na stałe (,urzędnicy ustaleni w służbie” albo „stali”) i mianowanych do odwołania (,urzędnicy prowizoryczni”). W u.p.s.c. zostały uregulowane zasady nawiązywania, zmiany i rozwiązywania stosunku służbowego a także prawa, obowiązki i odpowiedzialność urzędników. Stosunek zatrudnienia w służbie cywilnej miał charakter publicznoprawny. Mógł on być więc nawiązany, zmieniony, zawieszony lub rozwiązany jedynie na podstawie przepisów prawa publicznego ${ }^{4}$.

Zmiany w stosunkach służbowych urzędników państwowej służby cywilnej, na podstawie przepisów u.p.s.c,. mogły polegać na przeniesieniu urzędnika do innej miejscowości i na inne stanowisko służbowe, przeniesieniu urzędnika do „służby podlegającej innym przepisom” w tym samym dziale administracji państwowej, przejściu urzędnika na własną prośbę do innego działu administracji państwowej, przeniesienie w stan nieczynny, zwolnieniu urzędnika wybranego do organu ustawodawczego od sprawowania urzędu na czas trwania mandatu w tym organie. $^{5}$

\section{PRZENIESIENIE URZĘDNIKA DO INNEJ MIEJSCOWOŚCI I NA INNE STANOWISKO SŁUŻBOWE}

Możliwość przeniesienia urzędnika do innej miejscowości i na inne stanowisko służbowe przewidziana została $\mathrm{w}$ art. 52 u.p.s.c. Przesłanką takiego przeniesienia było „dobro służby”. Według pierwotnego brzmienia tego artykułu stanowisko służbowe, na które przenoszono urzędnika nie mogło być niższego stopnia służbowego niż dotychczas zajmowane, musiało zaliczać się do tej samej kategorii urzędniczej

op. cit., s. 52; B. Kuś, Służba cywilna w okresie II Rzeczypospolitej, „Roczniki Nauk Prawnych”, 2014, t. 24, nr 1, s. 146-148; M. Krzymkowski, Kwalifikacje zawodowe..., s. 97.

${ }^{3}$ M. Krzymkowski, Kwalifikacje zawodowe Kwalifikacje zawodowe urzędników w II Rzeczypospolitej, „Czasopismo Prawno-Historyczne”, 2015, t. 67, s. 97; idem, Urlopy funkcjonariuszy państwowej slużby cywilnej w II Rzeczypospolitej w Dzieje biurokracji, t. VI, Lublin 2016, s. 724.

${ }^{4}$ J.S. Langrod, op. cit., s. 742; W. Jaśkiewicz, op. cit., s. 100-105; J. Stelina, Prawo urzędnicze..., s. 44; E. Ura, op. cit., s. 52-54; A. Dubowik. Ł. Pisarczyk, op. cit., s. 54; M. Krzymkowski, Urlopy..., s. 724.

5 A. Łukaszczuk, Stużba cywilna II Rzeczypospolitej, „Przegląd Prawa i Administracji” 2010, t. 83 , s. $249-250$. 
i w tym samym dziale administracji państwowej. W okresie rządów sanacyjnych, na podstawie rozporządzeń prezydenta z dnia 7 października 1932 r. i 28 października 1933 r. wymagania te ograniczono w ten sposób, że przeniesienia do innej miejscowości i na inne stanowisko służbowe można było dokonać, gdy nie wiązało się to $\mathrm{z}$ obniżeniem posiadanej grupy uposażenia $\mathrm{w}$ tej samej kategorii urzędników i w tym samym dziale administracji państwowej. ${ }^{6} \mathrm{~W}$ wyroku z dnia 15 lutego 1924 r. Najwyższy Trybunał Administracyjny wyjaśnił, że pojęcie kategorii urzędników, o którym mowa była w art. 52 u.p.s.c., odnosiło sie do podziału ze względu na wymagania dotyczące poziomu wykształcenia (na podstawie art. 11 u.p.s.c.), ewentualnie do podziału na grupę urzędników i niższych funkcjonariuszy państwowych. Z tego względu NTA uznał, że urzędnicy na podstawie art. 52 nie mogli być przenoszeni na stanowiska wymagające niższego cenzusu wykształcenia lub na stanowiska niższych funkcjonariuszy państwowych. ${ }^{7}$

Przeniesienia dokonywał naczelny organ administracji lub organ bezpośrednio mu podległy, któremu zostało przekazane mianowanie na dane stanowisko służbowe. Jeżeli jednak na podstawie art. 17 u.p.s.c. mianowanie urzędników zostało przekazane zwierzchnikom instytucji podlegających bezpośrednio organom naczelnym, to przenoszenie urzędników z okręgu objętego właściwością działania zwierzchnika instytucji, który dokonał aktu mianowania do innego okręgu, należało do kompetencji naczelnego organu administracji (art. 52 ust. 2 u.p.s.c.). ${ }^{8}$

Przesiedlenie urzędnika wymagało czasu i podjęcia przez niego szeregu czynności z tym związanych. Dlatego, na podstawie art. 52 zdanie ostatnie, należało mu wyznaczyć odpowiedni termin i zwolnić na odpowiedni czas od pełnienia

${ }^{6}$ Rozporządzenie Prezydenta Rzeczypospolitej Polskiej z dnia 7 października 1932 r. w sprawie zmiany niektórych postanowień ustawy z dnia 17 lutego 1922 r. o państwowej służbie cywilnej (Dz.U. nr 87, poz. 737); Rozporządzenie Prezydenta Rzeczypospolitej Polskiej z dnia 28 października 1933 r. w sprawie zmiany ustawy z dnia 17 lutego 1922 r. o państwowej służbie cywilnej (Dz.U. nr 86, poz. 661); W. Jaśkiewicz, op. cit., s. 114; Państwowa stużba cywilna. Pragmatyka stużbowa urzędników państwowych, oprac. J. Kościołek, [Łódź] 1947 (dalej: J. Kościołek, op. cit.), s. 116117; L. Zieleniewski, Prawo urzędnicze. Ustawa o państwowej stużbie cywilnej, postępowanie dyscyplinarne, przepisy uposażeniowe, Kraków 1937, s. 48-49; ; J. Kafliński, Przepisy o państwowej stużbie cywilnej. Materiały do nauki do egzaminu praktycznego dla kandydatów na stanowiska urzędnicze w stużbie państwowej, Warszawa 1930, s. 15; A. Łukaszczuk, op. cit., s. 249.

7 Zbiór Wyroków Naczelnego Trybunału Administracyjnego, r. II, 1924, Warszawa 1925, s. 114-118; J. Stelina, Prawo urzędnicze..., s. 51; L. Zieleniewski, op. cit., s. 49; Ustawa o państwowej stużbie cywilnej (pragmatyka służbowa), oprac. W. Hekajłło, Warszawa 1924, s. 43 (dalej: W. Hekajłło, Ustawa); A. Dubowik. Ł. Pisarczyk, op. cit., s. 55-56.

8 J. Kościołek, op. cit., s. 116-118. W pierwotnym brzmieniu art. 52 brak było bliższego określenia odnośnie organów, które dokonywały przeniesienia. Mowa w nim była jedynie o tym, że dokonywała tego „właściwa władza”. Przepisy kompetencyjne pojawiły się w ustawie z dnia 21 marca 1924 r. w przedmiocie zmiany niektórych postanowień ustawy o państwowej służbie cywilnej (Dz.U. nr 29, poz. 286). 
służby, z uwzględnieniem stosunków rodzinnych i osobistych urzędnika. W okólniku ministra spraw wewnętrznych z dnia 1 kwietnia 1927 r. zostały skonkretyzowane terminy, o których była mowa w 52 zd. ostatnie. Mianowicie urzędnikom samotnym przysługiwał siedmiodniowy termin na przesiedlenie, urzędnicy posiadający rodzinę i prowadzący wspólne gospodarstwo domowe mieli zagwarantowane czternaście dni na dopełnienie wszelkich czynności związanych z przesiedleniem. Przy czym urzędnicy posiadający rodzinę a przesiedlający się bez niej traktowani byli jak samotni. Jeżeli później decydowali się sprowadzić rodzinę, to przysługiwało im zwolnienie od pełnienia służby ${ }^{9}$. Kwestie kosztów związanych z przesiedleniem regulowały rozporządzenia Rady Ministrów ${ }^{10}$.

\section{PRZENIESIENIE URZĘDNIKA \\ DO „SŁUŻBY PODLEGAJĄCEJ INNYM PRZEPISOM” W TYM SAMYM DZIALE ADMINISTRACJI PAŃSTWOWEJ}

Podstawę dla tej zmiany stosunków służbowych stanowił art. 52 ust. 5 u.p.s.c., który został dodany do tego artykułu na podstawie rozporządzenia prezydenta z dnia 7 października 1932 r. Na tej podstawie można było przenieść urzędnika ze względu na dobro służby do ,służby podlegającej innym przepisom” w tym samym dziale administracji państwowej, bez zmiany posiadanej przez niego grupy uposażenia. Warunkiem takiego przeniesienia był publicznoprawny charakter służby, do której następowało przeniesienie ${ }^{11}$.

Pojęcie „służby podlegającej innym przepisom” nie zostało w ustawie zdefiniowane. Przykładem takiej służby była w ministerstwie spraw wewnętrznych - policja państwowa, w ministerstwie sprawiedliwości - straż więzienna a w ministerstwie skarbu - straż graniczna i monopole państwowe ${ }^{12}$.

Gdy przeniesienie następowało $\mathrm{w}$ związku z przeprowadzeniem postępowania konkursowego lub wskutek decyzji właściwego organu, urzędnikowi wypłacano koszty takiego przeniesienia. Jeżeli zmiana miejsca wykonywania służby dokonywana była na prośbę urzędnika, to przyznanie środków finansowych na ten cel nie było obligatoryjne i zależało od decyzji właściwego organu.

${ }^{9}$ L. Zieleniewski, op. cit., s. 49.

${ }^{10}$ M.in.: rozporządzenie Rady Ministrów z dnia 16 lipca 1924 r. o należnościach za podróże służbowe, delegacje (odkomenderowania) i przeniesienia funkcjonariuszów państwowych, sędziów, prokuratorów oraz wojskowych (Dz.U. nr 72, poz. 703), rozporządzenie Rady Ministrów z dnia 28 marca 1934 r. o należnościach w razie pełnienia czynności służbowych poza zwykłem miejscem służbowem oraz w razie przeniesienia na inne miejsce służbowe (Dz.U. nr 35, poz. 320); J. Kościołek, op. cit., s. 212-261; W. Hekajłł, Ustawa, s. 41.

${ }^{11}$ J. Kościołek, op. cit., s. 116-118.

${ }^{12}$ Ibidem, s. 118. 


\section{PRZEJŚCIE URZĘDNIKA NA WŁASNĄ PROŚBE DO INNEGO DZIAŁU ADMINISTRACJI PAŃSTWOWEJ}

Przejście urzędnika do innego działu administracji państwowej na własną prośbę uzależnione było od zgody właściwego organu zwierzchniego (art. 53 u.p.s.c.). $\mathrm{W}$ takim przypadku, jeżeli przeniesienie wiązało się ze zmianą miejsca zamieszkania, urzędnikowi nie przysługiwał zwrot kosztów z tym związanych ${ }^{13}$. W odniesieniu do urzędów podległych ministrowi spraw wewnętrznych warunki i zasady przechodzenia do tego działu administracji zostały określone przez tegoż ministra w okólniku z dnia 9 czerwca 1931 r. W akcie tym minister m.in. zastrzegł sobie prawo decydowania o przyjęciu urzędników I kategorii oraz tych, którzy mieli otrzymać VII stopień służbowy. Urzędnicy niższych kategorii i stopni służbowych przyjmowani byli na podstawie decyzji właściwego wojewody ${ }^{14}$.

\section{PRZENIESIENIE URZĘDNIKA W STAN NIECZYNNY}

Na podstawie art. 54 u.p.s.c. można było przenieść urzędników stałych w stan nieczynny. Przepis ten był kilkukrotnie zmieniany na podstawie ustawy z dnia 21 marca 1924 r. ${ }^{15}$, ustawy z dnia 31 marca 1925 r. ${ }^{16} \mathrm{i}$ rozporządzenia prezydenta $\mathrm{z}$ dnia 7 października 1932 r. ${ }^{17}$

$\mathrm{W}$ przepisie tym sformułowane zostały dwie przesłanki przeniesienia urzędnika w stan nieczynny. Aby zaszedł określony w nich skutek wystarczyło, by zaistniała jedna $\mathrm{z}$ nich. Pierwszą stanowiła zmiana w organizacji władz i urzędów skutkująca czasowym brakiem odpowiedniego stanowiska służbowego tego samego stopnia służbowego i w tym samym dziale administracji państwowej. Na podstawie ostatniej ze wskazanych powyżej nowelizacji u.p.s.c. z przesłanki tej wyeliminowano warunek braku stanowiska służbowego „tego samego stopnia” [podkreśl. MK]. Drugą przesłankę stanowiło zajście takich okoliczności, które nie pozwalały ze względu na dobro służby na dalsze piastowanie przez urzędnika stanowiska służbowego tego samego stopnia służbowego w tym samym dziale administracji państwowej. Według nowelizacji z 1932 r. zmodyfikowano

${ }_{13}$ Ibidem, s. 122; W. Hekajłło, Ustawa, s. 42; J. Kafliński, Przepisy..., s. 15; J. Stelina, Prawo urzędnicze..., s. 51; A. Dubowik. Ł. Pisarczyk, op. cit., s. 56.

${ }_{14}$ Dziennik Urzędowy Ministerstwa Spraw Wewnętrznych, nr 6, poz. 157; W. Jaśkiewicz, op. cit., s. 114; L. Zieleniewski, op. cit., s. 49.

15 Ustawa z dnia 21 marca $1924 \mathrm{r}$. w przedmiocie zmiany niektórych postanowień ustawy o państwowej służbie cywilnej (Dz.U. nr 29, poz. 286).

16 Ustawa z dnia 31 marca 1925 r. o zmianie niektórych postanowień ustawy o państwowej służbie cywilnej (Dz.U. nr 43, poz. 294).

17 J. Kościołek, op. cit., s. 124-125; A. Łukaszczuk, op. cit., s. 249. 
ten przepis eliminując z niego konieczność braku stanowiska służbowego tego samego stopnia. Decyzję o przeniesieniu w stan nieczynny, według pierwotnego brzmienia art. 54, podejmowała Rada Ministrów na wniosek właściwego organu administracji centralnej. Po nowelizacji tego przepisu w 1932 r. kompetencję tę powierzono właściwemu organowi administracji centralnej za zgodą prezesa Rady Ministrów. Zgoda ta nie była wymagana przy przenoszeniu urzędników Sejmu i Senatu oraz Kontroli Państwowej. Podsekretarzy stanu i wojewodów przenosił w stan nieczynny prezydent na wniosek właściwego organu administracji centralnej, uchwalony przez Radę Ministrów. Również prezydent przenosił w stan nieczynny pozostałych urzędników, których sam powołał, przy czym konieczny był do tego wniosek właściwego organu administracji centralnej przedstawiony w porozumieniu z prezesem Rady Ministrów. Wcześniej, po zmianie ustawy w 1924 r., prezydent na wniosek Rady Ministrów dokonywał przeniesienia w stan nieczynny (lub w stan rozporządzalności) urzędników pierwszych czterech stopni służbowych. ${ }^{18}$

Przesłanki stanowiące podstawy dla przeniesienia urzędników w stan nieczynny były przedmiotem postępowań przed Najwyższym Trybunałem Administracyjnym. W jednym z orzeczeń NTA uznał, że reorganizacja urzędu mogła jedynie wtedy stanowić podstawę dla przeniesienia w stan nieczynny, jeżeli wiązała się z likwidacją etatu zajmowanego przez przenoszonego urzędnika, a nie można było zastosować rozwiązań przewidzianych w art. 52 u.p.s.c. $\mathrm{W}$ tym więc przypadku organ nie działał $\mathrm{w}$ zakresie swobodnego uznania. ${ }^{19}$ Inaczej rzecz się miała jeśli chodzi o drugą przesłankę z art. 54. Jak orzekł NTA w wyroku z dnia 21 października 1924 r. ocena, czy zaistniały okoliczności powodujące przeniesienie w stan nieczynny, jak i to, czy powstała okoliczność usprawiedliwiająca przeniesienie z punktu widzenia dobra służby, należało do zakresu swobodnego uznania organu posiadającego kompetencje na podstawie art. $54 .^{20}$

W okresie przebywania $\mathrm{w}$ stanie nieczynnym urzędnikom przysługiwało uposażenie służbowe (art. 55 u.p.s.c.). Nie mieli jednak prawa do zaliczki, jaka przysługiwała urzędnikom stałym na podstawie art. 45 u.p.s.c. Ta forma pomocy mogła być przyznana na podstawie decyzji właściwego organu zwierzchniego w wysokości trzymiesięcznego uposażenia, z obowiązkiem zwrotu w ratach mie-

${ }_{18}$ J. Kościołek, op. cit., s. 124-125; J. Kafliński, op. cit., s. 15-16; E. Ura, op. cit., s. 61-62; J. Stelina, Prawo urzędnicze..., s. 51.

19 Wyrok NTA z 4 lutego 1928 r. w sprawie Jana Strzępka, podkomisarza Policji Państwowej w Stanisławowie, który został przeniesiony w stan nieczynny, a na jego miejsce został mianowany inny funkcjonariusz (Zbiór Wyroków..., r. VI, 1928, s. 85-87; L. Zieleniewski, op. cit., s. 50).

${ }^{20}$ L. Zieleniewski, op. cit., s. 50. 
sięcznych w ciągu maksymalnie dwóch lat ${ }^{21}$. Urzędnikom pozostającym w stanie nieczynnym nie przysługiwały również dodatki funkcyjne ${ }^{22}$.

Po przeniesieniu urzędnika w stan nieczynny można go było w każdym czasie ponownie powołać do służby czynnej. W takim wypadku otrzymywał nominację na stanowisko tej samej kategorii i uposażenie tej samej grupy, które otrzymywał przed przejściem w stan nieczynny. W stanie nieczynnym urzędnik mógł pozostawać maksymalnie przez pół roku. Po upływie tego czasu zwalniano go ze służby. Jeżeli z jakichś powodów właściwy organ zaniedbał wydania decyzji o zwolnieniu ze służby, nie powodowało to automatycznego przedłużenia stanu nieczynnego i powstania po stronie urzędnika roszczeń $\mathrm{z}$ tytułu praw nabytych. $\mathrm{W}$ takim wypadku organ miał obowiązek zwolnić urzędnika ze służby z datą, w której upłynął termin sześciomiesięczny. ${ }^{23}$ Po zwolnieniu urzędnikowi przysługiwały uprawnienia wynikające z ustawy emerytalnej (art. 56 u.p.s.c.). ${ }^{24}$ Emerytury dla urzędników zostały uregulowane w ustawie z dnia 11 grudnia 1923 r. o zaopatrzeniu emerytalnym i funkcjonariuszów państwowych i zawodowych wojskowych ${ }^{25}$.

Odpowiednikiem stanu nieczynnego $\mathrm{w}$ resorcie spraw zagranicznych był stan rozporządzalności. Urzędników służby zewnętrznej tego resortu można było przenieść w stan rozporządzalności w analogicznych przypadkach, jak pozostałych urzędników państwowej służby cywilnej. Szczegółowe kwestie z tym związane zostały, na podstawie delegacji zawartej w art. 54 u.p.s.c., określone

${ }^{21}$ Art. 45 został uchylony na podstawie rozporządzenia Prezydenta Rzeczypospolitej Polskiej z dnia 28 października 1933 r. w sprawie zmiany ustawy z dnia 17 lutego 1922 r. o państwowej służbie cywilnej a zasady udzielania zaliczek zostały uregulowane w art. 11 rozporządzeniu Prezydenta Rzeczypospolitej Polskiej z 28 października 1933 r. o uposażeniu funkcjonariuszów państwowych (Dz.U. nr 86, poz. 663); J. Kościołek, op. cit., s. 111; W. Hekajłło, Ustawa s. 43; E. Ura, op. cit., s. 61-62.

${ }^{22}$ Art. 5 rozporządzenia prezydenta RP z 28 października 1933 r. o uposażeniu funkcjonariuszów państwowych; J. Kościołek, s. 111.

${ }^{23}$ Taki był sens wyroku NTA z 27 marca 1929 r. w sprawie kuratora oświaty, który został zwolniony ze służby prawie dwa miesiące po upływie sześciomiesięcznego okresu przebywania w stanie nieczynnym (Zbiór Wyroków..., r. VII, 1929, s. 183-185; L. Zieleniewski, op. cit., s. 52; W. Hekajłło, Przepisy o państwowej stużbie cywilnej. Pytania i odpowiedzi, Warszawa 1929, s. 26; J. Kafliński, Przepisy..., s. 16).

${ }^{24}$ Według pierwotnej treści art. 56 u.p.s.c. urzędnika pozostającego dłużej niż pół roku w stanie nieczynnym należało przenieść na emeryturę. Jednakże już na podstawie ustawy z dnia 28 lipca 1922 r. (Dz.U. nr 67, poz. 606) nowelizującej u.p.s.c. przepis ten zmieniono w ten sposób, że nadano mu treść (in fine): ,należy go zwolnić ze służby państwowej przy zastosowaniu odnośnych postanowień ustawy emerytalnej”; J. Kościołek, s. 111.

25 Dz.U. z 1934 r., nr 20, poz. 160. Później ustawa ta była nowelizowana dekretem Prezydenta Rzeczypospolitej Polskiej z dnia 22 listopada 1935 r. (Dz.U. nr 85, poz. 521), ustawą z dnia 12 marca 1938 r. (Dz.U. nr 17, poz. 125), dekretem Prezydenta Rzeczypospolitej Polskiej z 22 listopada 1938 r. (Dz.U. nr 91, poz. 626); J. Kościołek, op. cit., s. 111; E. Ura, op. cit., s. 61-62. 
w rozporządzeniu Rady Ministrów z 28 grudnia $1923 \mathrm{r} .{ }^{26} \mathrm{~W}$ akcie tym zostały doprecyzowane przesłanki przenoszenia w stan rozporządzalności. Przede wszystkim wskazano, że zmiany organizacyjne, o których była mowa w art. 54, musiały dotyczyć placówki zagranicznej. Organem właściwym do podejmowania decyzji o przeniesieniu w stan rozporządzalności urzędników I kategorii powyżej VIII stopnia służbowego był minister spraw zagranicznych. Przy czym liczba urzędników pozostających w stanie rozporządzalności nie mogła być większa niż 25 . Według rozporządzenia z 28 grudnia 1923 r. pracownicy służby zewnętrznej byli w lepszej sytuacji niż pozostali, gdyż półroczny okres pozostawania w stanie rozporządzalności mógł zostać przedłużony o dalsze pół roku zanim następowało zwolnienie ze służby. Zgodę na takie wyjątkowe rozwiązanie musiała wydać Rada Ministrów. Z dniem 1 listopada 1932 r. instytucja stanu rozporządzalności została zlikwidowana, a urzędnicy służby zewnętrznej zaczęli podlegać tym samym regułom, jakie obowiązywały pozostałych funkcjonariuszy państwowej służby cywilnej. ${ }^{27}$

\section{ZWOLNIENIE URZĘDNIKA \\ WYBRANEGO DO ORGANU USTAWODAWCZEGO \\ OD SPRAWOWANIA URZĘDU NA CZAS TRWANIA MANDATU \\ W TYM ORGANIE}

Podstawą dla zwolnienia urzędnika wybranego do organu ustawodawczego od sprawowania urzędu był artykuł 57 u.p.s.c. Stanowił on rozwinięcie art. 16 konstytucji marcowej. ${ }^{28} \mathrm{~W}$ myśl art. 57 urzędnik wybrany do Sejmu lub Senatu zwalniany był z obowiązku sprawowania swoich funkcji w czasie trwania man-

\footnotetext{
${ }^{26}$ Rozporządzenie Rady Ministrów z 28 grudnia 1923 r. o przenoszeniu w stan rozporządzalności urzędników Ministerstwa Spraw Zagranicznych (Dz.U. z 1924, nr 3, poz. 16).

27 J. Kościołek, s. 126-127; W. Hekajłło, Ustawa, s. 17, 43; Rozporządzenie Prezydenta Rzeczypospolitej Polskiej z dnia 7 października 1932 r.; podział urzędników na trzy kategorie wynikał z wymagań dotyczących poziomu wykształcenia (art. 11 u.p.s.c.). Według rozporządzenia Rady Ministrów z dnia 16 czerwca 1924 r. o ustanowieniu tabeli stanowisk we władzach i urzędach państwowych w resorcie spraw zagranicznych (Dz.U. nr 64, poz. 631) wśród urzędników służby zewnętrznej posiadających stopnie służbowe od VII włącznie znaleźli się: wicekonsul, sekretarz poselstwa (I i II klasy), konsul generalny (I i II klasy), zastępca komisarza generalnego Rzeczypospolitej Polskiej w Gdańsku, poseł nadzwyczajny i minister pełnomocny (I, II, i III klasy), minister rezydent, konsul generalny (I i II klasy), komisarza generalnego Rzeczypospolitej Polskiej w Gdańsku, ambasador.

${ }^{28}$ „Pracownicy państwowi i samorządowi z chwilą wyboru na posła, otrzymują na czas trwania mandatu poselskiego urlop. Przepis ten nie dotyczy ministrów, podsekretarzy stanu i profesorów wyższych uczelni. Lata spędzone na wykonywaniu mandatu poselskiego liczą się do lat służby." (art. 16 konstytucji marcowej - Dz.U. nr 44, poz. 267; J. Kościołek, op. cit., s. 130).
} 
datu. Jednakże w tym okresie nie przysługiwało mu uposażenie związane z pełnieniem urzędu. Okres wykonywania mandatu poselskiego lub senatorskiego był wliczany do czasu służby, czyli wysługi lat. Miało to znaczenie przede wszystkim dla obliczenia wysokości emerytury. Po wygaśnięciu mandatu w organie ustawodawczym urzędnik powracał na swoje poprzednie stanowisko służbowe lub na stanowisko równe stopniem w tym samym dziale zarządu państwowego. ${ }^{29}$

W rozwiązaniach przyjętych w ustawie o państwowej służbie uregulowano w sposób wyczerpujący zmiany w stosunku służbowym funkcjonariuszy państwowych. W normach zawartych w tych przepisach znalazł potwierdzenie publicznoprawnych charakter stosunku służbowego, co przejawiało się w uzależnieniu jego zmiany od decyzji właściwego organu państwa.

\section{CHANGES IN THE EMPLOYMENT OF THE STATE CIVIL SERVANTS IN THE SECOND POLISH REPUBLIC}

\section{Summary}

Legal situation of the civil servants in the Second Polish Republic was regulated by the act of the $17^{\text {th }}$ of February 1922 on the state civil service. Employment in the civil service was public in character. The changes in the employment of the state civil servants could take different forms. Among them were the following: transferring a civil servant to a different town and to a different position; transferring a civil servant to "a position which is subjected to different regulations" within the same department of the state administration; transferring to a different department of the state administration at the request of a civil servant; changing the employee's status to inactive state; releasing civil servants to a legislative body and freeing them from professional duties for the duration of their mandate in the said body.

\section{CHANGEMENTS DANS LES RELATIONS OFFICIELLES DES FONCTIONNAIRES DU SERVICE PUBLIC DE LA SECONDE RÉPUBLIQUE [DE POLOGNE]}

\section{Résumé}

Le statut juridique des fonctionnaires de l'État pendant la Seconde République était régi par la Loi du 17 février 1922 sur le Service public. La relation de travail des fonctionnaires du Service public avait le caractère de droit public. Les changements dans les rela-

${ }^{29}$ Ust. 2 art. 57 po kilku zmianach przyjął ostatecznie brzmienie: „Po wygaśnięciu mandatu urzędnik powraca do sprawowania swego urzędu względnie innego odpowiedniego urzędu bez obniżenia posiadanej grupy uposażenia, w tym samym dziale zarządu państwowego" (Dz.U. z 1932 r., nr 87, poz. 737; Dz.U. z 1933 r., nr 86, poz. 661);; J. Kościołek, op. cit., s. 129-130). 
tions officielles des fonctionnaires peuvent consister à un transfert d'un agent d'un service à un autre ou à un autre localité, à un transfert d'un fonctionnaire à un « service soumis à une autre réglementation » situé dans le même département de l'administration publique, à un transfert volontaire d'un fonctionnaire à un autre département de l'administration publique, à la mise d'un fonctionnaire à la retraite, à la libération d'un fonctionnaire élu à la législature de son poste pour la durée de son mandat. 